\title{
タンデムアーク・MAG 溶接法による高速すみ肉溶接法の研究*
}

\author{
奥井 信之 ${ }^{* *}$, 大賀 進 ${ }^{* *}$, 斉藤 忠雄 ${ }^{* *}$, 鈴木 友幸 ${ }^{* * *}$, 真木 成美 ${ }^{* * *}$, 本間 弘之 ${ }^{* * *}$
}

Study on High Speed Fillet Welding by Tandem Arc MAG Process*

\author{
by Nobuyuki OKUI**, Susumu OHGA**, Tadao SAITOH**, Tomoyuki SUZUKI***, Shigeyoshi MAKI*** \\ and Hiroyuki HONMA***
}

\begin{abstract}
Welded structures are composed of a large amount of the horizontal fillet joint whereby high speed fillet welding significantly influences on improvement of productivity. The "Tandem Arc MAG Process" here referred to is a newly developed process which realizes high speed horizontal fillet welding without any undercut by means of holding a stagnant molten metal formed between two electrodes. The authors have prepared the model of a molten metal pool, and researched relations among the displacement of molten metal and solidification point along a toe of weld metal. This research has been accompanied by studies on a distance between electrodes where stagnant molten metal is stably maintained as well as on current distribution to the leading and trailing electrodes. At the same time, a welding wire has been developed, that has excellent blowhole resistance in high speed welding. As a result, high quality welds have been obtained in a welding speed about 3 times as high as that of the conventional process.

The system is being applied to field work and proved that a process capability is improved to a great extent, thus the system is contributing greatly to productivity.
\end{abstract}

Key Words : High speed welding, Horizontal fillet welding, Tandem arc MAG processes, Stagnant molten metal, Electrodes distance, Welding current distribution to electrodes, Blowhole resistance wire, Displacement of molten metal, Solidification point of molten pool

\section{1. 緒言}

船体や橋梁などの溶接構造物は板・骨構造により構成さ れており, 殆どの場合, 脚長 $5 \sim 8 \mathrm{~mm}$ 程度のすみ肉溶接が 採用されている。これらの溶接の高速化を図ることは，単 に溶接の能率を向上させるばかりではなく，部材が製造ラ インに滞留する時間を短縮することになり，生産性の向上 に大きく貢献する．最近は製造ラインへ各種の自動化装置 が取り入れられる傾向にあり，溶接時間の短縮はますます 重要な課題になってきている.

溶接速度を增していくと，アンダーカットやハンピング ビード，ブローホールなどの発生が問題となることは良く 知られている。そこで, 水平すみ肉溶接の高速化における 欠陷の発生機構とそれらの防止方法について溶融池モデル を用いて検討した、タンデムアーク・MAG 溶接法におい て, 2 電極間に溶融金属の溜りを安定に保持するための溶 接条件を求めるとともに，耐ブローホール性の高い溶接ワ

\footnotetext{
*原稿受付 平成12年 1 月 19 日

**正員石川島播磨重工業俳 Member, IshikawajimaHarima Heavy Ind. Co., Ltd.

***正員 日鐵溶接工業侏 Member, Nippon Steel Welding Products \& Engineering Co., Ltd.
}

イヤを開発した ${ }^{9,10)}$.
これらにより, アンダーカットやブローホールがなく,
スムーズなビード形状が得られる溶接法を開発し, 実工事 に適用した。簡便な装置によって高品質の溶接が高速で得 られる実用性の高い溶接法であり，大幅な生産性の向上が 認められた。

\section{2. 高速溶接に関する考察}

ここでは，溶接の高能率化や高速化を四る上で直面する 種々の問題点について述べる.

\section{1 グラビティ溶接}

グラビティ溶接は，大変簡素な装置を用いて，一人の溶 接士が複数台を同時に操作できるため, 高能率の溶接法と して最近まで広範囲に使用されてきた。しかしこの方法で は, 棒継ざ箇所や溶接残し部などが多く発生し, 後がかり 作業が多い，また，溶接速度が遅いなどの欠点があり，現 状以上の高能率は得難い。例之ば, $15 \mathrm{~mm} / \mathrm{s}$ 以上の溶接速 度であれば，グラビテイ溶接より高能率が得られるという 試算がある。 


\section{2 サブマージアーク溶接}

サブマージアーク溶接において，棈円形の熱源形状を用 いることにより高速化を達成している報告1,2)がある。しか しサブマージアーク溶接は, 大型のフラックス供給, 回収 装置が必要であり，ここで目的としている水平すみ肉溶接 に㧍ける 5 6 $\mathrm{mm}$ 程度の脚長は得難い。

\section{3 ガスシールドアーク溶接}

ワイヤを高速で回転させて熱源形状を拡大することによ り高速化を図った報告3,4) や，3本のワイヤを使用して同様 の効果を得た報告(5)がある。これらはいずれの場合も大型 装置となり，複雑な制御が必要である。また，2 セットの 通常の $\mathrm{CO}_{2}$ 溶接卜ーチを自動走行台車に搭載した簡単な プロセスによる方法も多く見受けられる。このプロセスは 装置の構造が簡単であることが大きい利点であるが，溶融 プールが二つに別れているため, $6 \mathrm{~mm}$ 以下の脚長が得ら れないこと，溶接速度は $17 \mathrm{~mm} / \mathrm{s}$ 程度が限界であることな どが次点である。ここでは，この従来型の $\mathrm{CO}_{2}$ タンデム溶 接法の簡易性を失わずに前述の問題点を解決すべく，溶接 の高速化について種々の検討を行った。

\section{4 ガスシールドアーク溶接による高速水平すみ肉溶 接}

水平すみ肉溶接の高速化を図る場合, 要求される脚長に 見合った溶着量を得るために，より多くのワイヤ溶融量が 必要となる，換言すれば，溶接速度が大きければ大きいほ ど，より高い溶接電流（入熱）が要求されることになる. 一方，高速溶接においてはビード形成において次の問題が 生じてくる。

（1）溶接速度を增して行くと，溶融プールの止端部に生 じる凝固開始点： $\mathrm{X}_{\mathrm{s}}$ （溶融池先端部を基準としたク レータ幅が最大となる位置) が前方へ移動し，同時に 溶融金属の後退距離： $\mathrm{X}_{\mathrm{m}}$ を大きくする．この様子を Fig. Iに模式的に示す. $\mathrm{X}_{\mathrm{s}}<\mathrm{X}_{\mathrm{m}}$ のときにアンダー カットが発生する11.

（2）高電流により溶融プールに作用するアークカ（プラ

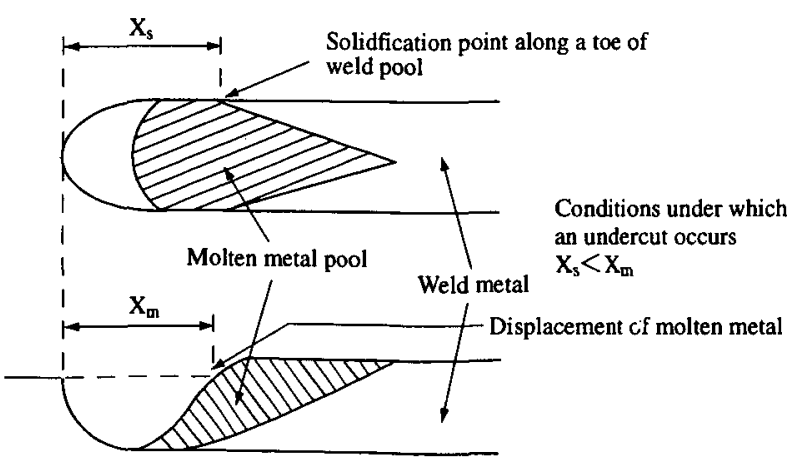

Fig. 1 Conceptual figure of molten metal pool.
ズマ気流）が強くなり，溶融金属を不規則に変化させ る。このため，高速溶接において正常なビード形状が 形成され難くなる。すなわち高電流，高速溶接では， この溶融金属の挙動を改善する必要がある.

(3) ショッププライマが塗布された鋼板にすみ肉溶接を 施工する時，プライマが分解してがスが発生する。こ のガスが原因となり，ピットやブローホールを発生さ せる。

これらに対して何らかの対策が必要である.本研究では, これら問題の対策を検討した。

\section{3. ガスシールドアーク溶接における高速水平すみ肉 溶接の研究}

\section{1 高速溶接プロセスの検討と試験要領}

前述のごとく溶接の高速化を達成する手段としては熱源 形状を拡大寸る方法もあるが，簡便な方法で高速化を図ろ うとする本研究には適していない，本研究の目的とするも のには，従来のタンデム方式を改良して溶融金属を 1 プー ルとする方法が最適であると考えられた。本プロセスにお ける二つの電極と溶融金属の状態を Fig. 2 に模式的に示 す. 狙いを下記に置いて検討した。

（1）タンデム方式において，電極間に溶融金属を安定に 保持できるように 2 本のワイヤを配置すること。

（2）熱源を二つの電極に分散して，溶融金属プールの止 端部の凝固位置 $\left(\mathrm{X}_{\mathrm{s}}\right)$ が前方へ移動する距離を抑制す ること。

（3）先行電極によるアーク力を電極間に安定に保持され た溶融金属（以降湯溜りと呼ぶ）によって吸収させて， 溶融金属の後退 $\left(\mathrm{X}_{\mathrm{m}}\right)$ を抑制すること。

(4) FCWによるスラグは，水平すみ肉溶接のビード形 成を容易にする効果が期待される。また FCW は高い 溶着率が得られるため, 比較的低電流の溶接条件を設 定できる。

この実験で用いた $\mathrm{CO}_{2}$ ガスシールドアーク溶接用の FCW はシームレスタイプで，フラックスの組成は主とし て $\mathrm{TiO}_{2}$ である. SM-50B の鋼板，板厚： $12.7 \mathrm{~mm}$ を用い て，逆 T字型継手を組み立てた。また，一般に市販されて いる無機ジンクプライマ塗布鋼板 (膜厚： $20 \mu \mathrm{m}$ ) も使用し た.

水平すみ肉溶接のビード形状・形成能力は横断面のマク 口組織から計測した余盛率およびアンダーカットの有無に より評価した。余盛率の模式図を Fig. 3 に示寸，溶接品質 の日標を脚長：5～6 mm，余盛率：20\%以下，溶接速度： $20 \mathrm{~mm} / \mathrm{s}$ 以上とした。 


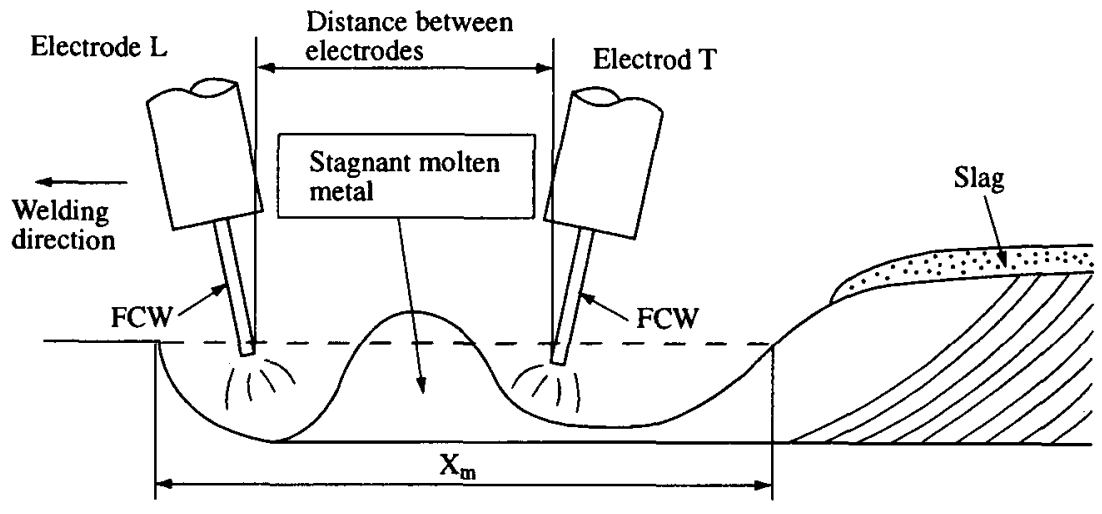

Displacement of molten metal

Fig. 2 Model of molten metal pool in 2-electrode welding (single pool).

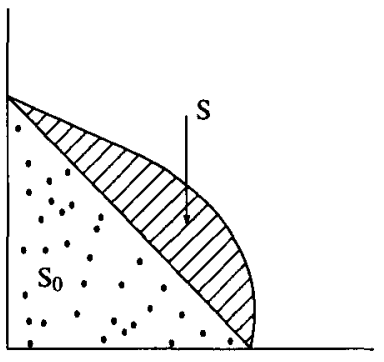

Rate of reinforcement of weld
$\frac{\mathrm{S}}{\mathrm{S}_{0}} \times 100(\%)$

Fig. 3 Rate of reinforcement in horizontal fillet welding.

\section{2 高速溶接条件の検討}

\section{2 .1 溶接ワイヤ $(\mathrm{FCW})$ の溶着率}

Fig. 4 は，本実験に用いた FCW の溶着率を 1 電極およ び 2 電極溶接について示したものである、この図から，目 標とする溶接速度： $20 \mathrm{~mm} / \mathrm{s}$ 以上では溶着率 $: 2.1 \mathrm{~g} / \mathrm{s}$ 以 上が必要であることがわかる，単電極が使用される場合に はより高い電流が必要となり，強いアーク力がビ一ド形成 に悪影響を与える。この奏験においても単電極の場合は， 溶接速度が $13.3 \mathrm{~mm} / \mathrm{s}$ 以上で顕著な凸型ビードが認めら れた。これに反してタンデム・ 2 電極の場合は同じ溶着率 を得るための合計電流は 1 電極の場合より高いが, 2 電極 に分散させることがでさる。すなうち，ビード形成に影響 を与える後行極の電流を 1 電極の場合より大幅に低く設定 できるので，タンデム方式が有利である。ささらに，同じ電 流による溶着率は大径ワイヤより小径ワイヤの方が多く, 言い換えると同じ溶着率を得るためには小径りイヤの方が 各電極の電流を低く設定できる。すなわち，大径ワイヤの 組合せにより，より小径のワイヤの組合せが有利である. 本実験では溶接電源と溶接条件の範囲を考慮して, 1.6 $\mathrm{mm}$ 径の FCW を用いた。

\section{2 .22 電極溶接条件の検討}

溶接条件が溶融金属の形状，および水平すみ肉溶接ビー

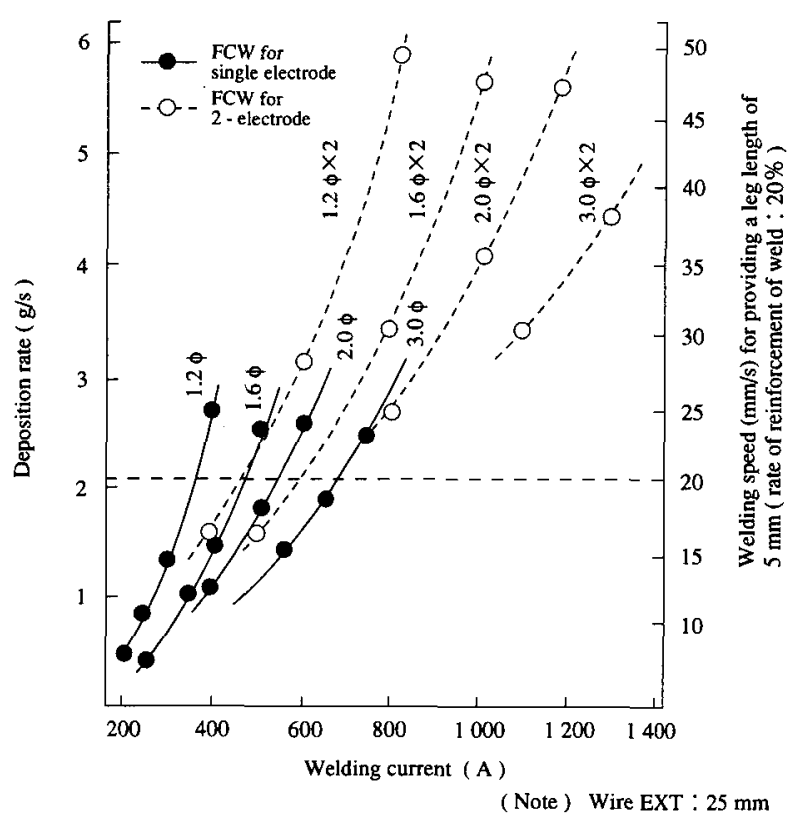

Fig. 4 Relationship between wire diameter, welding current and welding speed.

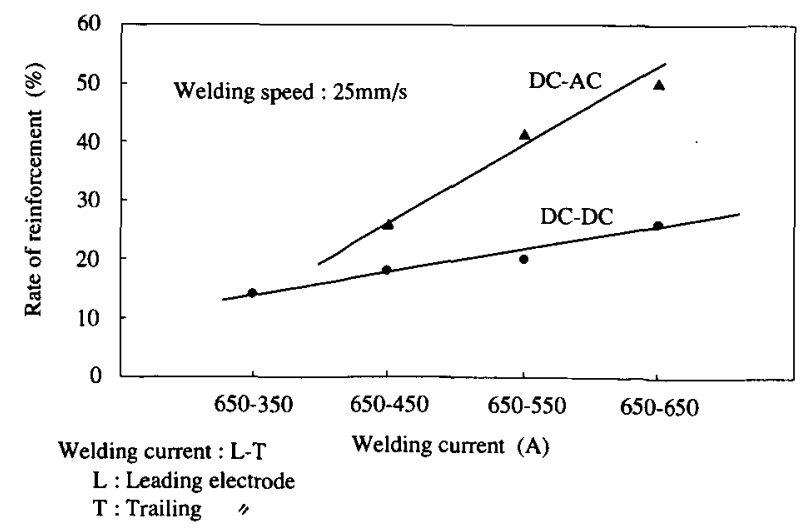

Fig. 5 Relations between power source polarity and bead formation. 
ドに与える影響について実験を行った。

（1）溶接電源特性の組み合わせ

溶接アークの方向によってビード形状が影響を受けるこ

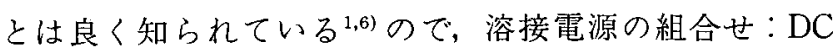
-DC と DC-ACについてビード形状を比較した。ビード横 断面のマクロ組織から余盛率を計測した結果を Fig. 5 に 示す.同図から, DC- $\mathrm{AC}$ の組み合わせでは凸形ビードにな り易く，DC-DCの方がビード形状が優れていることがわ かる.また DC-DCの方が，アークが安定している，そのた め以降の実験はすべて, DC-DCの組合せで行った.

\section{(2) 電極間距離}

電極間距離を変化させて溶接試験を行った。 Table 1 に 溶接条件と溶接結果をまとめて示す。この表から， 2 電極 水平すみ肉溶接における最適な極間距離は20〜 $40 \mathrm{~mm}$ の 範囲にあることがわかる。この範囲内では湯溜りが電極間 に安定して形成され，溶融金属の後退 $\left(\mathrm{X}_{\mathrm{m}}\right)$ は小さく，そ のため良好なビード形状が得られている．極間距離が 10 $\mathrm{mm}$ 以下では湯溜りが形成されず，アークの相互作用に よってスパッタが頻繁に発生している。これらが良好な ビード形成を阻害している，反対に，極間距離が50 mm 以 上の場合は溶融金属が二つに分かれ，凸型ビードや部分的 なアンダーカットが生じる.

(3) 先行極と後行極の電圧

Table 1 に示す溶接条件で, 先行極の電垝のみを変化さ せて溶接試験を行った．先行極の電圧とアンダーカットと の関係を Fig. 6 に示す.アーク電圧の低い領域ではアン ダーカットの発生が少ない. 低いアーク電左ではアーク力 が影響する範囲が狭いために電極間に湯溜りを安定して保 持し易い. 先行極の電圧が高い場合は，電極間の湯溜りが 安定しないなめ，不規則なビードとなる，反对に，後行極 の電圧が低すぎた場合はアークの広がりがなくなり，湯溜 クが後方に流れて凸形ビードになり易い，後行極のアーク
圧力が湯溜りの幅全体に及ぶ必要があるため, 後行極の電 圧はやや高めに設定する必要がある ${ }^{6,10)}$.

\section{(4) 先行電極と後行電極の電流配分}

後行電極の電流 $\left(\mathrm{I}_{\mathrm{T}}\right)$ を先行電極の電流 $\left(\mathrm{I}_{\mathrm{L}}\right)$ に比べて極 度に小さくすると, 後行電極のアーク圧力が不足するため 2 電極間に湯溜りが形成され難くなる．また逆に， $\mathrm{I}_{\mathrm{T}}$ を $\mathrm{I}_{\mathrm{L}}$ より大きくすると，後行極のアーク圧力が大きくなり，溶 融プールの後退 $\left(X_{m}\right)$ を大くする．野村らは索，2電極夕 ンデム・サブマージアーク溶接における溶融池現象の検討 から, $\mathrm{I}_{\mathrm{T}} / \mathrm{I}_{\mathrm{L}}$ が0.7付近で高速溶接限界速度が最も拡大され， この条件の下では先行電極によるくぼみと後行電極による

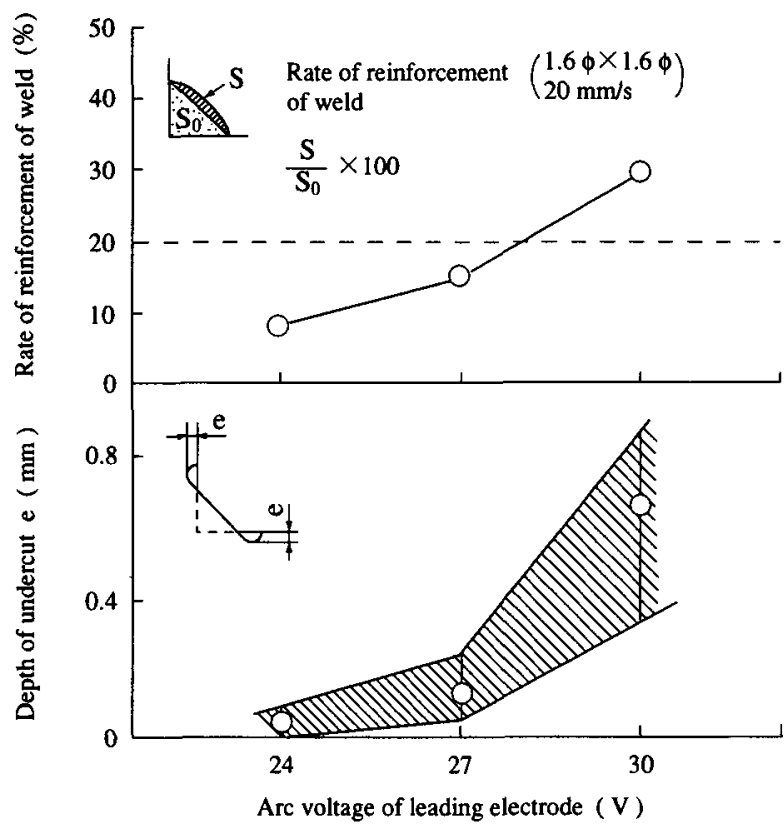

Fig. 6 Influence of arc voltage of the leading electrode on undercut.

Table 1 Effect of distance between electrodes on bead formation (DC-DC, $20 \mathrm{~mm} / \mathrm{s}$ ).

\begin{tabular}{|c|c|c|c|c|c|c|c|c|c|}
\hline \multirow[b]{2}{*}{ 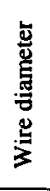 } & \multicolumn{5}{|c|}{ Welding parameter } & \multirow[b]{2}{*}{$\begin{array}{l}\text { Arc } \\
\text { Condition }\end{array}$} & \multirow{2}{*}{$\begin{array}{l}\text { Formation } \\
\text { of } \\
\text { stagnant } \\
\text { molten } \\
\text { metal }\end{array}$} & \multirow[b]{2}{*}{$\begin{array}{l}\text { Bead } \\
\text { shape }\end{array}$} & \multirow{2}{*}{$\begin{array}{l}\text { Rate } \\
\text { of } \\
\text { reinforcement } \\
\text { of } \\
\text { weld \% }\end{array}$} \\
\hline & 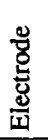 & 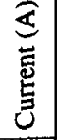 & 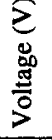 & 롤 & 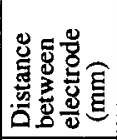 & & & & \\
\hline \multirow{4}{*}{$\begin{array}{l}1.6 \\
\times \\
1.6\end{array}$} & \multirow[t]{2}{*}{$\mathrm{L}$} & \multirow[t]{2}{*}{380} & \multirow[t]{2}{*}{24} & \multirow{4}{*}{20} & 10 & $\begin{array}{l}\quad \text { × } \\
\quad \text { (Unstable } \\
\text { arc : excess } \\
\text { spatters) }\end{array}$ & $\begin{array}{l}\text { (Not } \\
\text { formed) }\end{array}$ & (Undercut) & 23 \\
\hline & & & & & 20 & 0 & $\begin{array}{c}\bigcirc \\
\text { (Stable) }\end{array}$ & & 10 \\
\hline & \multirow[b]{2}{*}{$\mathrm{T}$} & \multirow[b]{2}{*}{300} & \multirow[b]{2}{*}{26} & & 40 & 0 & 0 & 0 & 16 \\
\hline & & & & & 70 & 0 & $\begin{array}{c}\triangle \\
\text { (Unstable, } \\
2 \text { pools) }\end{array}$ & $\Delta \begin{array}{l}\text { (Undercut, } \\
\text { convex } \\
\text { bead) }\end{array}$ & 38 \\
\hline
\end{tabular}


くぼみの深さが等しくなると述べている，更に， $\mathrm{I}_{\mathrm{T}}$ が増加 してゆくと後行アーク力の一部が先行電極にも及ぶように なり，先行電極アークは抑制され，溶鋼に対して作用する 起行的なアーク力は減少すると述べている. タンデムアー ク MAG 溶接においても同様のことが言えると考れられ， 2 電極間に湯溜りを安定して保持するためには $\mathrm{I}_{\mathrm{L}}$ は, この 作用による減少分だけ $\mathrm{I}_{\mathrm{T}}$ より大きく設定する必要がある. 本溶接法の場合においても, $\mathrm{I}_{\mathrm{T}} / \mathrm{I}_{\mathrm{L}}$ が $0.7 \sim 0.9$ 範囲で最も 发定した湯溜りが形成された. $\mathrm{I}_{\mathrm{T}} / \mathrm{I}_{\mathrm{L}}: 0.8 \sim 0.9$ の場合につ いて, 合計電流と溶接速度を変化させて溶接し, ビード形 状と脚長を調査した。 その結果を Fig. 7 に示す。例えば, 溶接速度 : $25 \mathrm{~mm} / \mathrm{s}$, 脚長 : $5 \mathrm{~mm}$ を目標とした場合は, 合 計電流： $680 \mathrm{~A}, \mathrm{I}_{\mathrm{T}} / \mathrm{I}_{\mathrm{L}}$ が 0.8 程度が適正溶接条件であろう ことがこの四からわかる。

Fig. 8 に本プロセスによるビード横断面のマクロ組織の 例を示寸.

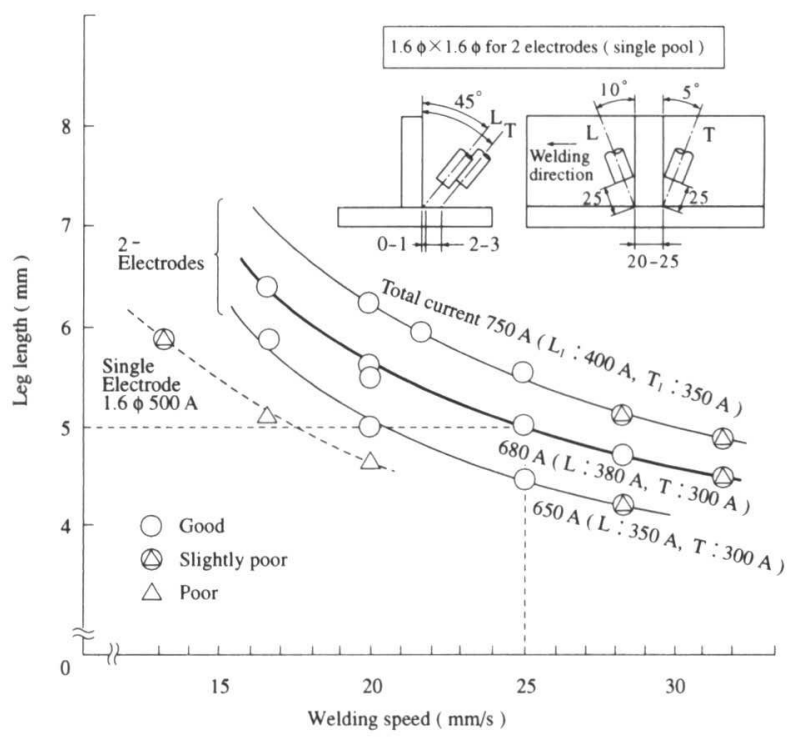

Fig. 7 Relations between welding conditions and welding results.

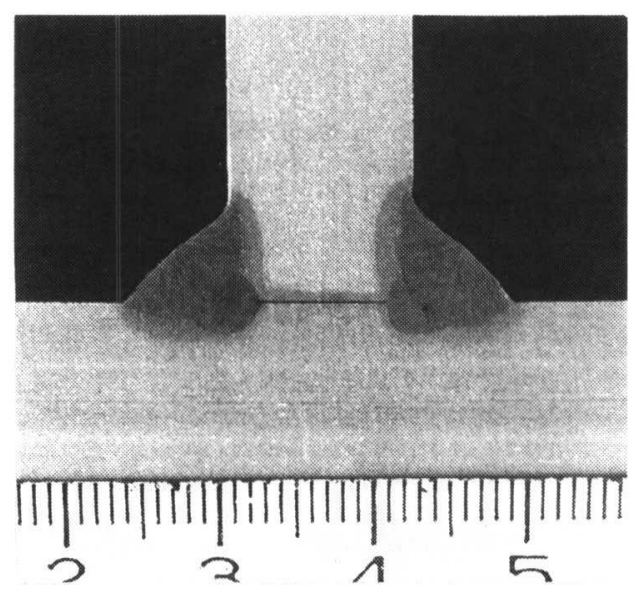

Fig. 8 Cross sectional macro structure of horizontal fillet welding (2-electrode, $20 \mathrm{~mm} / \mathrm{s}$ ).

\section{3 溶接試験結果の考察}

（1）電源特性の組合せ

溶接電源の組合せで， DC-DCの方が DC-ACより良好 なビード形状が得られる理由は次のごとく考えられる。す なわち, 各電極のアークは電流の流れる方向によって相互 に吸引あるいは反撥する。一方の電極が $\mathrm{AC}$ の場合はこの 吸引・反撥を繰り返していると考えられ，反撥の時間は溶 融金属の後退を助長している。これに対して,両方とも DC の場合は常に吸引されており，溶融池後方に向かう後行極 によるアーク圧力が小さくなる1．すなおち，後行極のア一 クは溶融金属の後退を抑制する方向に一定して働いてい る.さらに, $\mathrm{AC} の$ 場合は電流值が時間的に変化しており, その電磁圧力も時間的に変化している.これに対して DC は電流の脈動がなく, 常に一定の電磁圧力が溶融金属に作 用している。このため, 電極間に湯溜りを安定に保持し易 い.この結果は, 伊藤らによる電極特性とビード形状に関 する実験結果 ${ }^{6)}$ と一致している.

(2) アンダーカットの防止

アンダーカットを防止するためには, 溶融金属の後退 $\left(\mathrm{X}_{\mathrm{m}}\right)$ を抑制すると同時に, 凝固開始位置 $\left(\mathrm{X}_{\mathrm{s}}\right)$ の前方へ の移動を抑制し， $\mathrm{X}_{\mathrm{m}}<\mathrm{X}_{\mathrm{s}}$ を満足させることが必要である. タンデム 2 電極における 1 プールが形成される場合では, この凝固開始位置は極間距離を差し引いた值で評価すべき である. Fig. 9 に, デカンテイション試験から計測した凝固 開始位置 (溶融金属の前端から凝固点までの距離)： $\mathrm{X}_{\mathrm{s}}^{\prime}$, 電 極間距離：D, 先行極の電圧, 溶接速度の関係を示す.ここ に $\mathrm{X}_{\mathrm{s}}^{\prime}=\mathrm{X}_{\mathrm{s}}-\mathrm{D}$ である.極間距離：20〜 $40 \mathrm{~mm}$ で $\mathrm{X}_{\mathrm{s}}^{\prime}$ が大き

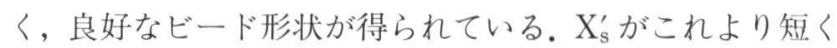
なるとアンダーカットや凸型ビードを生じさせる.さらに， 先行極のアーク電圧が高い場合も $\mathrm{X}_{\mathrm{s}}^{\prime}$ が短くなり, 西らの 報告1) と同じ傾向を示している。溶接速度がさらに増大し $30 \mathrm{~mm} / \mathrm{s}$ を越えると, $\mathrm{X}_{\mathrm{s}}^{\prime}$ が短くなり溶接ビードは悪化し ている.

一方溶融金属の後退は, 溶融金属の温度差による表面張 力対流 ${ }^{8)}$ や溶融池後方に向かうアーク圧力 ${ }^{1)}$ にって生じ ると言われている．本溶接法の場合は，先行極のアーク圧 力が 2 電極間に形成される湯溜りによって吸収されるの で, $X_{m}$ は先行極には影響されず, 後行極の特性によっての み支配されると考えてよい。高速溶接における高電流は 2 電極に分散されるため，後行極によるアーク圧力を小さく 抑えることができる。また，後行極を前進角とすること， 及び 2 電極のアークが互いに吸引する方向に傾斜すること により溶融池後方に向かうアーク圧力が軽減される ${ }^{1)}$.こ れらにより，本溶接法における $\mathrm{X}_{\mathrm{m}}$ の増大は十分な範囲に 抑制されており，アンダーカットを防止できる条件： $\mathrm{X}_{\mathrm{m}}<$ $\mathrm{X}_{\mathrm{S}}$ を満足していると考えられる.

これまでの検討結果をもとに，ワイヤの狙い位置，ト一 千角度, 極間距離, 先行電極のアーク電圧, 先行電極と後 


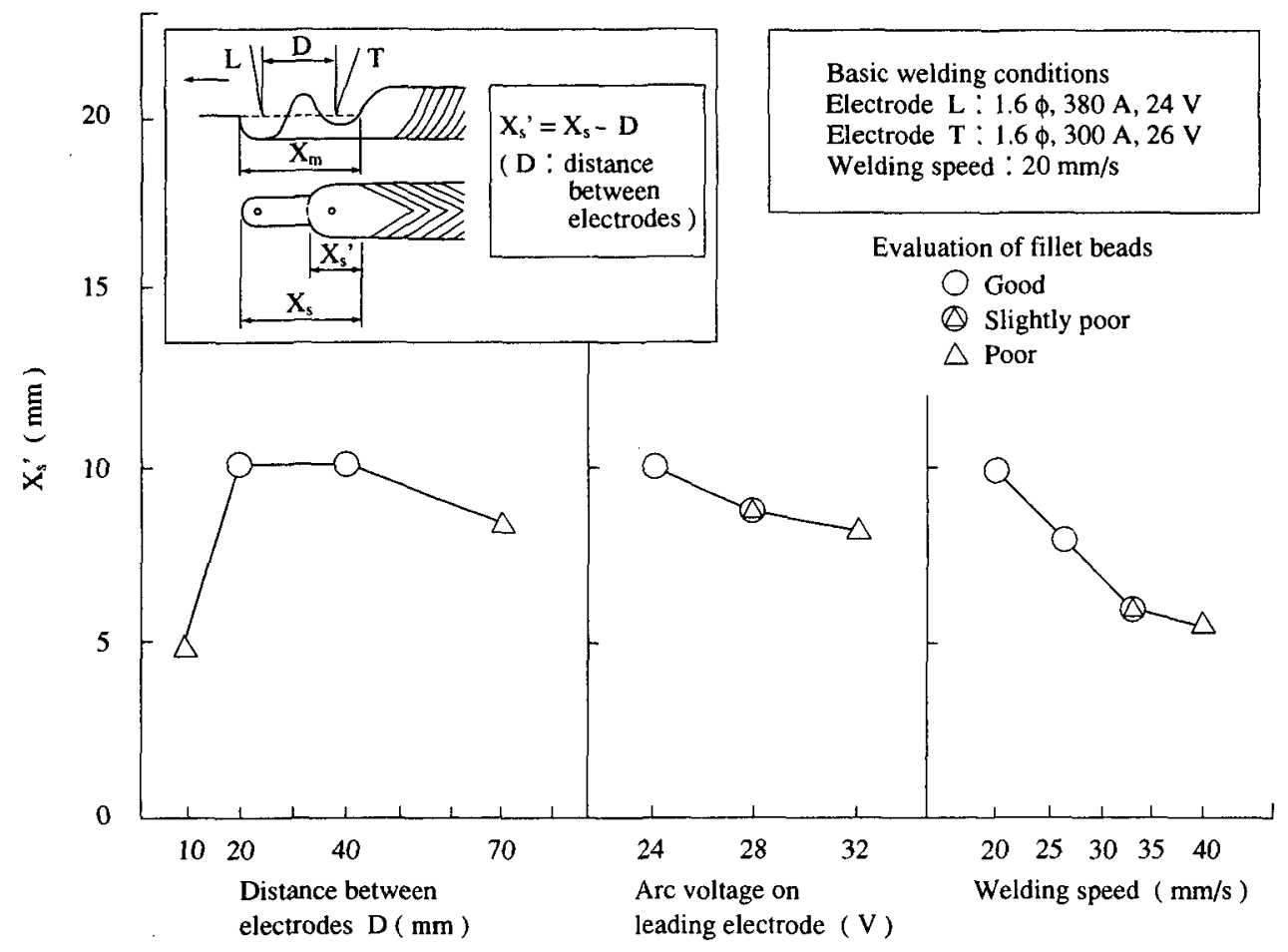

Fig. 9 Influence of welding conditions on solidification point along a toe of weld pool.

行電極の電流比などを最適值に設定した。これにより，溶 接速度： $20 \mathrm{~mm} / \mathrm{s}$ 以上で, 脚長 : $5 \sim 6 \mathrm{~mm}$ の良好なビード 形状が確保されている.

\section{4 耐ブローホール性の高い溶接ワイヤの開発}

ショッププライマが染布された鋼板が水平すみ肉溶接さ れる場合，プライマが分解してがスを発生させ，ピットや ウォームホールなどの欠宿の原因となる。このため従来の 方法では，プライマを除去するかまたは溶接速度を下げる 必要があった。プライマ整布鋼板におけるこれらの久陷防 止を目的として，耐ブローホール性の高いワイヤを開発し た.

(1) 溶接ワイヤの選定

ルチール系のフラックス入りワイヤはスラグ生成量が多 く，スラグ被包性に優れているため平滑なビード形状を得 る上で適している．本溶接法では，後行電極でビードを形 成せしめるので，少なくとも後行電極にはこのワイヤを用 いる.これに反して，後行電極にメタルフラックス入りワ イヤやソリッドワイヤを用いると，スラグの被包性が悪く なり，スラグによるビードの平滑化は期待できない。また 先行極にもルチール系ワイヤを用いると，スラグの生成量 がさらに多くなり，平滑なビード形成に有利である。な挍， この場合はスラグが過多となって，スラグの巻き込みや ビード表面にガス圧痕が発生しやすくなるので，スラグ生 成成分である $\mathrm{TiO}_{2}$ の含有量を調整している。

（2）耐ブローホール性の向上策

ショッププライマ塗布鋼板の溶接において問題となるブ

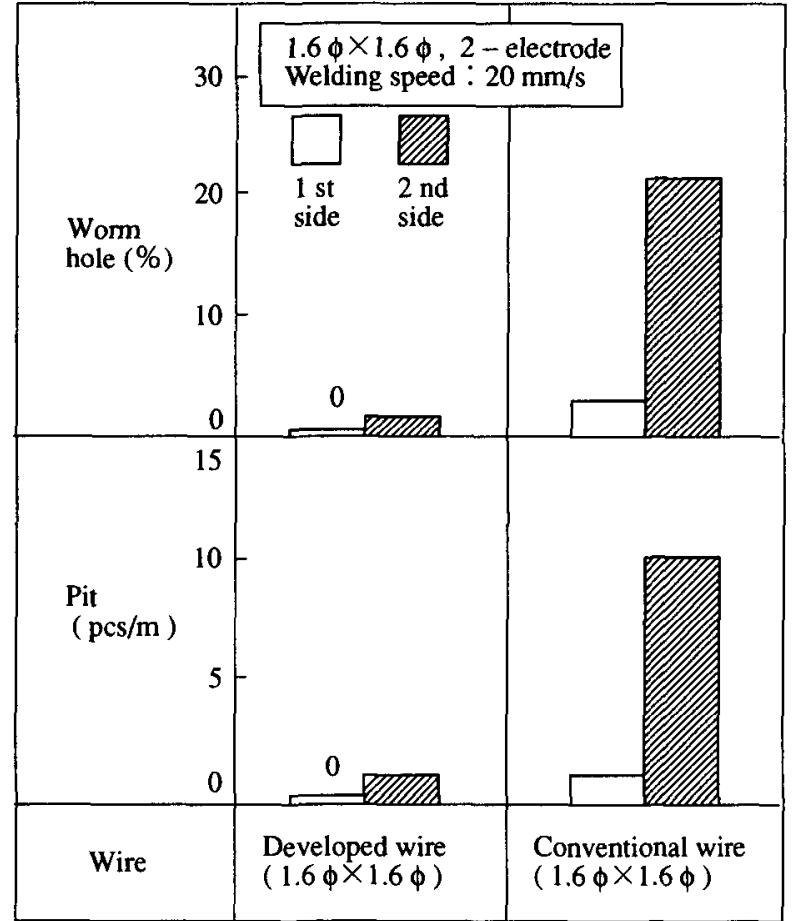

Fig. 10 Comparison of primer resistance between the developed wire and a conventional wire at welding speed of $20 \mathrm{~mm} / \mathrm{s}$ (primer: inorganic zinc primer).

ローホールやピットなどの欠陥を防止するために，ルチー ル系フラックス大りワイヤの構成成分を改良した。これら を以下に列記する。 
（A）金属弗化物及び金属炭酸塩など高温において分解し やすい成分を添加することによってアークの吹き付け 力を増加させ，溶融金属の覺汼を促して溶融金属に取 り込まれたプライマ一熱分解ガスの放出を容易にす る.これらの化合物をそれぞれ適正な範囲で添加した。

(B) 金属弗化物の添加量を調整してスラグの融点，粘度 を低く抑えることによって，スラグが溶融金属を覆う までの時間を遅らせ，プライマー分解ガスの放出を促 進する。

(C) FCW の拡散性水素を非常に低いレベルに制御し， フラックス組成とスラグ量を最適化する。

無機ジンクプライマ塗布鋼板における耐ブローホール性 について，今回開発した FCW を用いる 2 電極高速すみ肉 溶接と従来型の FCW の場合を比較した。結果を Fig. 10 に 示寸. Fig. 10 から溶接速度 : $20 \mathrm{~mm} / \mathrm{s}$ において, 今回開発 した FCW は従来の FCW に比べてピットおよびウォール ホールが大幅に減少していることがわかる.この新しく開 発した FCW : $1.6 \mathrm{~mm}$ 径は, 水平すみ肉溶接の高速化に大 きく貢献している。

\section{4. 高速すみ肉溶接の実工事への適用}

\section{1 溶接装置}

船体構造のロンジ材は逆 T字型継手であり,この両側の すみ肉溶接を同時に行うために片側 2 トーチ（两側で 4 トーチ）を搭載した溶接装置を開発した。この装置はロン
ジ材に沿って，自走台車を部材に倣わせる所謂斜交倣いで 走行させ，同時にトーチを溶接線に倣わせる方式を採用し ている. 非常に簡単な構造であり, 操作も大変簡単である.

\section{2 実工事への適用}

この溶接装置は, 船体構造のアッセンブリ工程における ロンジ材の溶接やビルトアップ $\mathrm{H}$ 型材の製造工程に使用 されている.今日まで $30,000 \mathrm{~m}$ 以上の継手に適用された. 実工事への適用状況を Fig. 11 に示す。これまで片側単電 極の溶接プロセスがロンジ材の溶接に長く適用されてき た。また，2プール方式のタンデム溶接法も試験的に適用 された. Table 2 に, 今回開発した 2 電極 1 プール溶接プロ

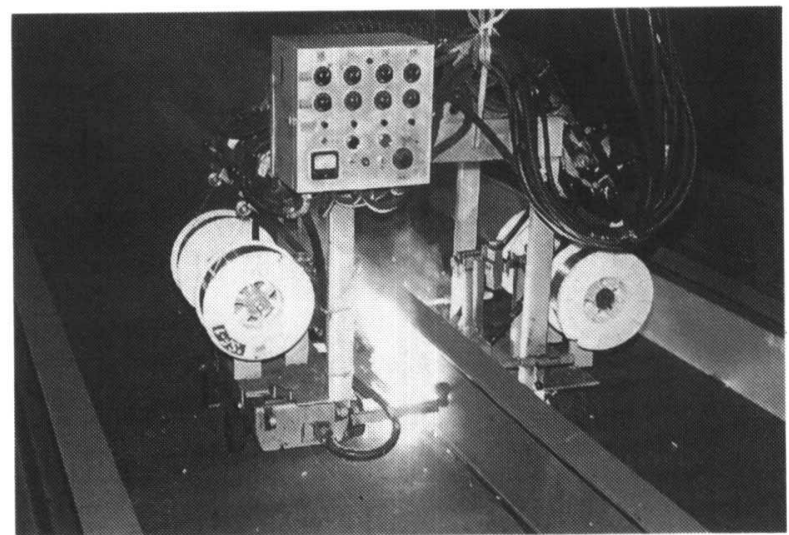

Fig. 11 Application of the "Twin Arc MAG Process" to field works.

Table 2 Comparison of characteristics among three kinds of twin arc processes.

\begin{tabular}{|c|c|c|c|}
\hline Process & Single Twin & Tandem Twi & Arc Process \\
\hline Properties & Arc Process & Conventional Process & New Process \\
\hline $\begin{array}{l}\text { Layout of } \\
\text { welding torches }\end{array}$ & 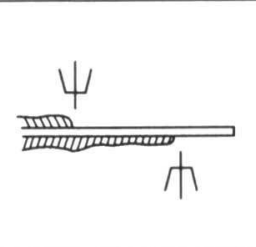 & 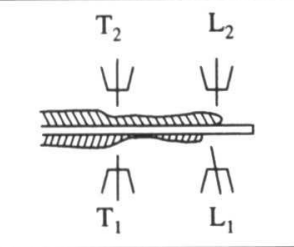 & $\frac{\mathrm{L}_{2}^{\mathrm{L}_{2}}}{4 \phi}$ \\
\hline $\begin{array}{l}\text { Formation of molten } \\
\text { metal pool }\end{array}$ & One-pool & 2-pool & One-pool \\
\hline \multirow{2}{*}{ welding parameters } & Right $: 1.2 \phi / 280 \mathrm{~A}$ & Right $\begin{array}{l}\mathrm{L}_{1}: 1.6 \phi / 400 \mathrm{~A} \\
\mathrm{~T}_{1}: 1.2 \phi / 270 \mathrm{~A}\end{array}$ & Right $\begin{array}{l}\mathrm{L}_{1}: 1.6 \phi / 400 \mathrm{~A} \\
\mathrm{~T}_{1}: 1.6 \phi / 310 \mathrm{~A}\end{array}$ \\
\hline & Left : $1.2 \phi / 280 \mathrm{~A}$ & $\begin{array}{ll}\text { Left } & \mathrm{L}_{2}: 1.6 \phi / 400 \mathrm{~A} \\
& \mathrm{~T}_{2}: 1.2 \phi / 270 \mathrm{~A}\end{array}$ & Left $\begin{array}{l}\mathrm{L}_{2}: 1.6 \phi / 400 \mathrm{~A} \\
\\
\mathrm{~T}_{2}: 1.6 \phi / 310 \mathrm{~A}\end{array}$ \\
\hline Leg length & Minimum $5 \mathrm{~mm}$ & Minimum $6.5 \mathrm{~mm}$ & Minimum $5.5 \mathrm{~mm}$ \\
\hline welding speed & $6.7 \mathrm{~mm} / \mathrm{s}$ & $15 \mathrm{~mm} / \mathrm{s}$ & $20 \mathrm{~mm} / \mathrm{s}$ \\
\hline Process capability & $500 \mathrm{~m} / \mathrm{d}$ & - & $1400 \mathrm{~m} / \mathrm{d}$ \\
\hline
\end{tabular}


セスの特徵を従来法と比較して示す。単電極，およU゙従来 型のタンデム溶接法に比べて, 溶接速度のみならず 1 日当 たりの溶接量も 3 倍に向上している. 一方この溶接法は, 従来型のタンデム溶接（2プール万式）に比べてより小さ い脚長が得られ, さらにピットやウォームホール, アンダー カットの発生を $1 / 3 \sim 1 / 4$ に減少させることができ, 実用性 に優れた溶接プロセスであると言える。このプロセスを導 入することにより, 高品質, 高能率の溶接が得られ, 生産 性を大幅に向上させることができる。

\section{5. 結言}

船体や橋梁などの溶接構造物はすみ肉継手が多い、この すみ肉溶接の高能率化と生産性の向上を目的として，タン デムアーク・MAG 溶接法をべースとした溶接の高速化に ついて研究した．高速溶接で問題となるアンダーカットの 防止方法として，2 電極間に湯溜りを安定に保持する方法 が有効であることを明らかにした，同時に，無機ジンク・ ショッププライマ塗布鋼板の高速溶接において，優れた耐 ブローホール性を有する溶接ワイヤを開発した。得られた 結果を以下にまとめる。

(1) 高速溶接では溶融金属の止端部に生じる凝固開始位 置 $\left(X_{\mathrm{s}}\right)$ が前方へ移動し，同時に溶融金属の後退 $\left(\mathrm{X}_{\mathrm{m}}\right)$ が大きくなる． $\mathrm{X}_{\mathrm{m}}>\mathrm{X}_{\mathrm{s}}$ の時にアンダーカットが発生 する。

（2） 2 電極間に湯溜りを安定して保持させて，先行極の アークカをこの湯溜りに吸収させることによって， $\mathrm{X}_{\mathrm{m}}$ の後退及び $\mathrm{X}_{\mathrm{s}}$ の前進を防止できる、湯溜りは次の方 法によって電極間に安定して保持させた。

・極間距離：15〜 $40 \mathrm{~mm}$ をキープする.

- 先行極の電流 $\left(\mathrm{I}_{\mathrm{L}}\right)$ と後行極の電流 $\left(\mathrm{I}_{\mathrm{T}}\right)$ の比 $\left(\mathrm{I}_{\mathrm{T}} /\right.$ $\mathrm{I}_{\mathrm{L}}$ ）を0.7〜0.9程度とする。

・先行極のアーク電圧を比較的低い電圧とする. これらにより溶接速度： $20 \mathrm{~mm} / \mathrm{s}$ 以上で，アンダー カットの発生がない条件である $\mathrm{X}_{\mathrm{m}}<\mathrm{X}_{\mathrm{s}}$ を満たすこ とができた
（3）耐ブローホール性に優れた溶接ワイヤを開発した. スラグ被怆性の確保，溶融金属の㩭挥作用の付加，又 ラグ粘性の調整, 拡散性水素の低減などに重点を置い た。

（4）このプロセスは奏工事に適用され，溶接欠陥の減少， 高能率，生産性の向上に大きく貢献している。

\section{謝 辞}

本研究は，新日本製鐵株式会社，新日鐵溶接工業株式会 社，石川島播磨重工業株式会社の三社による共同研究とし て実施され，関係各位から多大のご協力を頂きました。ま た本稿をまとめるにあたり，大阪大学工学部教授 豊田政 男工学博士に多くの貴重な助語を頂きました.ここに記し， 㕌く御礼申し上げます。

\section{参 考 文 献}

1）西, 藤田, 長谷場, 小原：高速サブマージアーク溶接法の研究 (第 1 報），本誌，51-10（1982）68-74.

2）小原, 藤田, 長谷場, 西：高速サブマージアーク溶接法の研究(第 2 報)，本会論文集，1-2（1983）31-36。

3）野村, 杉谷, 村山：高速回転アーク隅肉溶接法の開発, 本会論文 集 4-3（1986）18-23.

4）杉谷, 小林, 村山, 中野, 溝㴊：高速回転アーク多電極隅肉自動 溶接装置の開発，NKK 技報，No.124（1988）93-100。

5）藤村, 井手, 井上：高速アーク溶接法の開発, 三菱重工技報, Vol. 26 No. 3 (1989) 223-228.

6）伊藤，池田，山内：サブマージアーク・タンデム方式における ビード形成に関する研究，本誌，39-10（1970）101-108.

7) 野村, 杉谷, 辻：サブマージアーク溶接溶融池現象, 本誌, 51-9（1982） 43-51.

8）安藤，西川，井上：高電流・高速 MIG 溶接に扔ける溶融池現象 に関する研究，本誌，40-4 (1971） 51-55。

9) Okui, Ohga, Saitoh, Suzuki, Maki, Homma : Study of High Speed Fillet Welding by Tandem Arc MAG Process, EVAL MAT 89, Nov. 1989 803-810.

10）鎌田，鈴木，奥井：高速水平すみ肉溶接法（HS-MAG 法），ガ イドブック『アーク溶接の自動化技術』本会，溶接法研究委員会 編, June, 1995 II -92-II-96. 